\title{
KAJIAN KRITIS FILSAFAT MUTAWAHHID IBNU BAJJAH (Tahapan Kedewasaan Intelektual Dan Spiritual Manusia)
}

\author{
Abdulloh Hanif \\ Sekolah Tinggi Agama Islam Al-Fithrah Surabaya \\ 4bdhan@gmail.com
}

Diterima 22 Mei 2019 | Direview 30 Mei 2019|Diterbitkan 20 Juni 2019

\begin{abstract}
:
Ibn Baijah, the first Muslim philosopher in the Western world, who had given a wide influence both to his own Islamic philosophy and many Christian Western thinkers, was a controversial figure. His thoughts besides opening the gate of independent philosophy without the interests of religious polemic also contained purzles and images of pessimism. His work Tadbir al-Mutawabhid clearly illustrates the impossibility of the formation of al-Farabi's ideal city, also presupposes the impossibility that even divine intellectual perfection cannot change the social conditions of a damaged city. On the other hand, those who have been enlightened with their connection with the Active Intellect (al-qaql al-fa'al) through solitude actually show a passive and pessimistic attitude that looks down on the material world so that the happiness they get is merely personal happiness. This kind of attitude, even though born from universal forms of spirituality, has a resemblance to Schopenhauer's philosophical view which is pessimistic and considers the world and the will of life as obstacles to happiness. But on the other hand, the philosophy of Ibn Baijah also shows a ladder of psychological maturation, as is the ladder of existence in Kierkegaard's philosophy, where the result is a condition of spirituality that is of the divine value.
\end{abstract}

Keywords: Ibnu Bajjah, Mutawahbid, Ittis al, Pesimism.

\begin{abstract}
Abstrak:
Ibnu Bajjah, seorang filsuf muslim pertama di dunia Barat, yang telah memberikan pengaruh luas baik bagi filsafat Islam sendiri maupun banyak pemikir Barat Kristen, adalah sosok yang kontroversial. Pemikirannya selain membuka gerbang filsafat yang independen tanpa kepentingan polemik religius juga mengandung teka-teki dan gambaran sikap pesimistis. Karyanya Tadbir al-Mutawahbid menggambarkan dengan jelas di samping ketidakmungkinan terbentuknya kota ideal al-Farabi, juga mengandaikan ketidakmungkinan bahwa kesempurnaan intelektual yang bersifat ilabiah sekalipun tidak dapat merubah kondisi sosial suatu kota yang rusak. Sebaliknya pibak-pihak yang sudah tercerabkan dengan keterbubungannya dengan Akal Aktif (al-'aql al-fa'al) melalui penyendirian justru memperlibatkan sikap pasif dan pesimistis yang memandang rendah dunia material sehingga kebahagiaan yang didapatkannya hanyalah kebahagiaan pribadi semata. Sikap semacam ini, sekalipun labir dari bentuk-bentuk spiritualitas universal, memiliki kemiripan dengan pandangan filsafat Schopenhauer yang pesimis dan menganggap dunia dan kehendak hidup sebagai penghambat kebahagiaan. Namun di sisi lain, filsafat Ibnu Bajjah juga memperlihatkan sebuah tangga pendewasaan psikologis, sebagaimana tangga eksistensi dalam filsafat Kierkegaard, di mana hasilnya adalab kondisi spiritualitas yang bernilai ketuhanan.
\end{abstract}

Kata Kunci: Ibnu Bajjah, Mutawabhid, Ittis al, Pesimisme.

\section{Pendahuluan}

Islam di Spanyol (Andalusia) telah mencatat satu lembar budaya yang sangat brilian dalam bentangan sejarah Islam. Ia berperan sebagai jembatan penyeberangan yang dilalui ilmu pengetahuan Yunani-Arab ke Eropa pada abad ke-12. Atas inisiatif al-Hakam (961-976 M), karya-karya ilmiah dan filosofis diimpor dari Timur dalam jumlah besar, sehingga Cordova dengan perpusatakaan dan universitas-universitasnya mampu menyaingi Baghdad sebagai pusat utama ilmu pengetahuan di dunia Islam. ${ }^{1}$ Filsafat sebagai salah satu bagian yang menjadi konsen pengembangan peradaban Islam di Andalusia berbeda secara prinsipil dengan filsafat yang berkembang di dunia Timur Islam. Di sana filsafat lahir secara langsung dihadapkan dengan pertengan antara teolog di satu sisi dan doktrin tasawuf di sisi lain, sehingga menjadikan filsafat tidak lagi murni uapaya eksplorasi intelektual yang bebas, ia menjadi budak agama yang harus melayani agama dengan baju rasional filsafat.

Filsafat Islam di Timur, lebih dari dua abad sejak al-Farabi hingga Ikhwan as- Șhafa, dapat dikatakan diwarnai corak pemikiran Neoplatonis murni, terutama melalui teori

${ }^{1}$ Badri Yatim, Sejarah Peradaban Islam: Dirasah Islamiah II, (Jakarta: Raja Grafindo Persada, 2014), h. 101.

DOI: $10.18592 /$ jiiu.v\% \%vi\%i.2771 
emanasi. Teori ini dielaborasi sedemikian rupa sehingga meskipun para filsuf muslim Timur sudah berkenalan dengan konsep-konsep Aristoteles, yang terjadi justru secaman transformasi Neoplatonisasi. Konsep-konsep Aristoteles tentang penggerak pertama dan metafisikanya dirangkai secara paksa ke dalam jaringan metafisika dan astronomi Neoplatonis, dan upaya ini terjadi di kalangan filsuf hingga Ibnu Sina, dan bahkan dalam beberapa tempat Neoplatonisasi juga terjadi dalam beberapa pemikiran di luar filsafat. Dengan alasan demikian Ibnu Rusyd menganggap bahwa emanasi Ibnu Sina sama sekali non-Aristotelian. ${ }^{2}$ Sebaliknya, Ibnu Rusyd di Andalusia memulai kajian burhani Aristotelian yang menjadi basis kajian politik filsafat Plato. ${ }^{3}$

Dalam konteks Barat Islam, Al-Jabiri menjelaskan bahwa filsafat demonstratif (burban) di Andalusia muncul dalam konteks yang berbeda dengan konteks kemunculan filsafat di Timur, baik filsafat Isma'iliyah atau filsafat al-Kindi, al-Farabi, dan Ibnu Sina. Filsafat Islam muncul dan hidup dataran Timur dalam konteks agama, yaitu konteks di mana mereka didominasi oleh Ilmu Kalam dengan bentuk pemerintahannya yang tidak jelas, menghubungkan dasar naql dan 'aql sebagai dasar politik: membela aqidah dengan dasar rasional. ${ }^{4}$ Sebaliknya di Andalusia, diskursus filsafat lahir tanpa kecenderungan sama sekali untuk mendamaikan persoalan "akal" dan "naql / wabyu", serta pendamaian antara "filsafat" dan "agama". Keterbebasan filsafat dari belenggu kultural yang mengharuskan setiap keilmuan memiliki legalitas "agama" di Andalusia meberikan peluang totalitas para filsuf untuk melakukan upaya berfilsafat secara independen dari doktrin keyakinan. Filsafat Islam di Barat, pada akhirnya, memiliki varian yang lebih beragam di bandingkan di Timur.

Ibnu Bajjah, seorang yang dianggap sebagai filsuf pertama di Barat Islam Andalusia, memperlihatkan independensi tersebut sebagai seorang filsuf murni yang tidak terikat dengan kepetingan mengurai problematika "filsafat" dan "agama", sekalipun dalam beberapa hal ia masih mengikuti berbagai teori para filsuf Islam di Timur. Ia masih menggunakan konsep "Akal Aktif” (al-aql al-fa'al) untuk menunjukkan semacam tabir pembatas antara realitas ketuhanan dan dunia materi, akan tetapi konsep tersebut tidak ditunjukkan sebagai bagian dari unsur keagamaan bagi kalangan filsuf, yang menjadi metafor atas doktrin-doktrin agama yang sudah ada. Para filosof yakin bahwa Akal Aktif bersifat ilahi dan mutlak terpisah dari eksistensi spasiotemporal kita. Hubungan antara Wujud Ilahi dan eksistensi kita terjadi melalui iluminasi dalam pengertian pengetahuan intelek yang diperoleh secara intensional, dan sebagai konsekuensi kesatuan melalui penyerapan dalam pengertian realisasi diri kita, ketika diri dengan cara tertentu bersatu dengan Realitas-Realitas Ilahi. ${ }^{6}$

Dalam karyanya Tadbir al-Mutawahbid, Ibnu Bajjah menggambarkan konsep Akal Aktif secara eksplisit bukan berhubungan dengan tujuan penyatuan manusia dengan Tuhan sebagaimana banyak diupayakan oleh para sufi, sekalipun secara implisit memiliki keserupaan. Dalam hubungannya dengan tindakan manusia secara psikologis terjadi dari pertimbangan akal dan kondisi kejiwaannya, Akal Aktif di posisikan Ibnu Bajjah sebagai tujuan semua tindakan dapat dikatakan bermakna bagi kehidupan pelakunya. Al-Jabiri dalam Nahnu wa at-Turas juga menjelaskan bahwa yang menarik dari Ibnu Bajjah adalah bahwa ia mengadopsi ide emanasi untuk menjelaskan persoalan penciptaan dan kenabian, dan istilah "penyucian jiwa" digunakan untuk menyatakan pencapaian kebahagiaan dan keabadian jiwa. Kenabian dalam hal ini adalah teori kepemimpinan politik, sebagaimana termuat dalam

\footnotetext{
${ }^{2}$ Mehdi Ha'iri Yazdi, Menghadirkan Cahaya Tuhan: Epistemologi Iluminasionis dalam Filsafat Islam, terj. Husein Heriyanto, (Bandung: Mizan, 1994), h. 63.

${ }^{3}$ Aksin Wijaya, Nalar Kritis Epistemologi Islam, (Yogyakarta: Penerbit Teras, 2014), cet. III, h. 91-92.

${ }^{4}$ Muhammad Abid al-Jabiri, Nahnu wa at-Turats, (Bairut: al-Markaz as-Tsaqafi al-Arabi, 1993), h. 173.

${ }^{5}$ Muhammad Abid al-Jabiri, Kritik Pemikiran Islam: Wacana Baru Filsafat Islam, terj. Burhan (Yogyakarta: Fajar Pustaka Baru, 2003), h. 108-109.

${ }^{6}$ Mehdi Ha'iri Yazdi, Menghadirkan Cahaya Tuhan, h. 63.

${ }^{7}$ Muhammad Abid al-Jabiri, Nahnu wa at-Turats, h. 169.
} 
keseluruhan Tadbir al-Mutawahbid-nya Ibnu Bajjah. Namun berbeda dengan al-Farabi yang sangat menganjurkan seorang filosof untuk menjadi pemimpin, namun Ibnu Bajjah tidak mengarahkan filsafat politiknya sebuah teori kepemimpinan, akan tetapi untuk menjelaskan tentang manusia penyendiri sebagai manusia ideal yang hidup di kota yang tidak sempurna, dan bagaimana ia mengatur kesempurnaan dirinya dan realitasnya. ${ }^{8}$

Ibnu Bajjah juga mengkritik bahwa puncak ma'rifat dapat dicapai dengan akal semata, bukan dengan jalan sufi melalui al-qalb, atau al-zanq. Ia mengkritik konsep uəlab tasawuf alGhazali. Pengasingan diri secara total dari masyarakat manusia bertentangan dengan tabiat manusiawi sebagai makhluk sosial. ${ }^{9}$ Meskipun demikian, al-mutawahbid bukanlah seorang ma'rifat, melainkan orang-orang yang mampu mencapai penyatuannya dengan Intelek Aktif (active intellect atau aql al-fa'al), ${ }^{10}$ dan menyendiri dari dunia sosial yang tidak ideal. Sekalipun demikian, Ibnu Bajjah tidak hanya seorang filsuf gemilang dengan berbagai karya dan pengaruh yang luas, ia merupakan realitas keterpengaruhan yang penuh paradoks. Kehidupan yang dibayangkannya sama sekali berbeda dengan realitas faktual semasa kehidupannya, namun kehidupan pribadinya bukan sepenuhnya seperti yang ia teorikan. Kematiannya yang terlalu cepat, karya yang tidak terselesaikan, bahasa yang terlampau kacau, namun memiliki pengaruh yang sangat luas hingga lintas peradaban dan keilmuan, tetap menyisakan ruang samar yang terbuka untuk dieksplorasi dan ditelusuri.

\section{Sejarah Kehidupan Ibnu Bajjah}

Di kalangan umat muslim, Ibnu Bajjah, yang memiliki nama asli Abu Bakar Muhammad ibn Yahya ibn Saikh ibn Bajjah, adalah salah satu filsuf muslim yang penting di dunia Barat. Ia juga akrab dikenal dengan nama latin Avempace. Ia disebut-sebut sebagai filsuf muslim pertama di Barat. Ia dikenal baik melalui komentar-komentarnya tentang Aristoteles maupun melalui karya utamanya, Tadbir al-Mutawahbid (Regimen of The Solitary), yang menyatakan bahwa kota sempurna ${ }^{11}$ hanya dapat terjadi melalui kesempurnaan individuindividu yang memiliki kesatuan intelek (kecerdasan) dengan Intelek. Aktif (Active Intellect/al'aql al-fa'al). ${ }^{12}$ Sekalipun ia dilingkupi oleh popularitas, hanya sedikit yang mengetahui tentang kehidupannya secara mendalam. Ibnu al-Imam, murid Ibnu Bajjah, menjelaskan sejumlah karya-karya filsafat dan menulis sejarah singkat kehidupan Ibnu Bajjah, di mana ia menjelaskan bahwa filsafat Ibnu Bajjah adalah karya yang menakjubkan (miraculous). Karya tersebut termasuk Paraphrase of Aristotle's Physics, sejumlah penjelasan tentang logika al-Farabi, risalah politik yang berjudul The Conduct of the Solitary dan Epistle on Conjunction. ${ }^{13}$

Ibnu Bajjah lahir menjelang akhir abad kelima Hijriyah atau akhir abad kesebelas Masehi, sekitar tahun $1082 \mathrm{M}$ di Zaragoza, salah satu wilayah Andalusia. ${ }^{14}$ Kemudian ia pindah ke Sevilla dan Granada, dan meninggal pada usia yang relatif muda di Fez, Maroko, pada tahun 1138 M. Banyak yang mengatakan bahwa Ibnu Bajjah meninggal akibat diracun. ${ }^{15}$ Ia adalah keturunan Yahudi, anak seorang pandai emas. Semasa hidupnya, Ibnu

\footnotetext{
${ }^{8}$ Abdul Rahman Badawi, Mausuat al-Hadharoh al-'Arabiyah al-Islamiyah, (Amman: Dar al-Faris, 1995), jilid: I, h. 104.

9Sirajuddin Zar, Filsafat Islam: Filosof dan Filsafatnya, (Jakarta: Rajawali Press, 2012), h. 196.

${ }^{10}$ Majid Fakhry, A History of Islamic Phylosophy, (New York: Columbia University Press, 1983), h. 261.

${ }^{11}$ Mengacu pada al-Madinah al-Fadhilah dalam pemikiran Al-Farabi, di mana Ibnu Bajjah menggantinya dengan istilah al-Madinah al-Kamilah.

${ }^{12}$ Seyyed Hossein Nasr, Islamic Philosophy from Its Origin to The Present: Philosophy in The Land of Prophecy, (New York: State University of New York Press, 2006), h. 114.

${ }^{13}$ Majid Fakhry, Islamic Philosophy, Theology and Mysticism: A Short Introduction, (Oxford: Oneworld, 1997), h. 87.

${ }^{14}$ Wahyu Murtiningsih, Para Filsuf dari Plato Sampai Ibnu Bajjah, (Yogyakarta: Ircisod, 2012), h. 334.

${ }^{15}$ De Boer menyebutkan bahwa racun yang diminum Ibnu Bajjah adalah karena kecemburuan seorang ahli medis. Sedangkan Lenn E. Goodman, menduka bahwa kematian Ibnu Bajjah sudah direncanakan. Ia dieksekusi atas permintaan dokter dan anggota istana pesaingnya, yaitu Ibnu Zuhr yang agaknya dulu pernah
} 
Bajjah berprofesi sebagai seorang dokter, musisi, penulis lagu dan puisi populer dengan "bakat lirik yang mengagumkan". Ia juga menjadi penyair bagi golongan al-Murabitun yang dipimpin oleh Abu Bakr Ibrahim Ibn Tafalwit. ${ }^{16}$ Ia juga merupakan pemikir kreatif dan ikonoklastik, seorang penyulut "pemberontakan Andalusia" yang menjalankan observatorium miliknya sendiri dan memberikan kontribusi orisinal pada teori fisika, dengan uraiannya tentang gerak proyektil (gerak peluru). ${ }^{17}$

Dalam usianya yang masih dua puluhan ia sempat tampil sebagai wazir Gubernur Berber, Ibn Tifalwith, ipar laki-laki pangeran al-Murabitun 'Ali. Abu Bakr ibn Ibrahim, ipar dari pangeran al-Murabitun Ali, yang menjadi Gubernur Zaragoza, juga menjadikan Ibnu Bajjah sebagai teman dekatnya dan menteri pertama. ${ }^{18}$ Ia juga sempat dipenjara beberapa bulan saat diutus mejadi duta kepada mantan penguasa yang masih merdeka, karena ia dianggap menyerahkan nasibnya kepada para penakluk. ${ }^{19}$ Ibnu Bajjah pindah ke Sevilla pada tahun $1118 \mathrm{M}$ setelah kejatuhan Zaragoza, dan menyusun beberapa karya di sana. Setelah itu ia ditahan di penjara kerajaan al-Murabitun di Fez, di mana ia meninggal pada tahun $1138 .{ }^{20}$

Kehidupan Ibnu Bajjah, disamping dilingkupi situasi politik yang rumit, ia juga sempat menempati posisi penting berkat kekuasaan yang berhasil direbut oleh suku Berber. Ia sempat menjadi wazir kerajaan al-Murabitun, satu kerajaan yang lahir dari orang-orang Berber. Puncak kehidupan Ibnu Bajjah dapat dikatakan terjadi pada masa kejayaan alMurabitun, termasuk juga karya-karyanya juga seakan-akan menggambarkan situasi sosial pada waktu itu dan termasuk juga kondisi pribadinya. Ia lahir kira-kira ketika al-Murabitun dipimpin oleh Yusuf bin Tasyifin, raja yang mengantarkan al-Murabitun pada kekuasaannya yang membentang luas. Akan tetapi sangat disayangkan Ibnu Bajjah meninggal sebelum ia sempat menikmati kejayaannya sebagai seorang filosof, ia belum sempat menyelesaikan karya-karyanya, termasuk Tadbir al-Mutawabhid yang masih dianggap belum selesai. Ia tidak menjelaskan secara terperinci tentang keadaan orang-orang penyendiri ini, akan tetapi menyimpulkannya dalam risalah tadbir-nya hanya sebagai pandangan realitas empiris manusia, yang mana ia merupakan keseluruhan dari setiap tindakannya, sehingga karya Ibnu Bajjah ini merupakan karya yang belum lengkap. ${ }^{21}$ Menurut Majid Fakhry, mengutip dari Ibnu Tufayl, dua hal yang menghambat kejeniusannya: kematiannya yang terlalu cepat dan ambisinya pada duniawi. ${ }^{22}$ Penyebab-penyebab ini setidaknya memperlihatkan bahwa seorang filsuf secemerlang Ibnu Bajjah tidak mampu lepas dari pengaruh lingkungan hidupnya, situasi kecenderungan umum masyarakat Andalusia pada waktu itu. Dalam catatan De Boer disebutkan bahwa hidupnya sangat singkat, dan ia mengakui bahwa ia bukanlah seseorang yang bahagia; ia sering merindukan kematian sebagai tempat perlindungannya yang terakhir. Kebutuhan material, pengisolasian intelektualitasnya, mungkin telah menurunkan spiritnya. Naskah tulisannya yang berlimpah menunjukkan dengan jelas bahwa ia tidak dapat merasakan kenyamanan dalam lingkungannya. ${ }^{23}$

\section{Karya-karya Ibnu Bajjah}

mengecam Malik, dan dikenal sebagai ayah dari Avenzoar, sahabat, murid, dan sejawat Ibnu Rusyd. Lihat T.J. De Boer, The History of Pholosophy in Islam, terj. Edward R. Jones B.D. (London: Lucas \& Company LTD, 1970), h. 176. Dan Seyyed Hossein Nasr dan Oliver Leaman (ed.), Ensiklopedi Tematis Filsafat Islam: Buku Pertama, terj. Tim penerjemah mizan (Bandung: Mizan, 2003), h. 368.

${ }^{16}$ Wahyu Murtiningsih, Para Filsuf dari Plato Sampai Ibnu Bajjah, h. 334.

${ }_{17}$ Seyyed Hossein Nasr dan Oliver Leaman (ed.), Ensiklopedi Tematis Filsafat Islam, h. 366.

18 T.J. De Boer, The History of Pholosophy in Islam, h. 176.

${ }^{19}$ Seyyed Hossein Nasr dan Oliver Leaman (ed.), Ensiklopedi Tematis Filsafat Islam, h. 367.

20 T.J. De Boer, The History of Pholosophy in Islam, h. 176.

${ }^{21}$ Abdul Rahman Badawi, dalam Mausuat al-Hadharoh al-'Arabiyah al-Islamiyah, h. 103.

${ }^{22}$ Majid Fakhry, A History of Islamic Philosophy, h. 260.

${ }^{23}$ T.J. De Boer, The History of Pholosophy in Islam, h. 176-177. 
Abdul Rahman Badawi mencatat, ada tiga kumpulan karya-karya Ibnu Bajjah yang tersebar di berbagai tempat dalam jumlah yang banyak. ${ }^{24}$ Di Oxford ada sekitar 29 karya. Kemudian di Tashkent, Uzbekistan juga terdapat tiga karya: (1) risalah fi al-mutaharrik (2) risalah fi al-wabdah wa al-wahidah (3) maqalah fi al-fahsh 'an al-quwah al-nuru'iyah. Miguel Asin Palacios juga mempublikasikan 4 karya: (1) fi an-nabat (2) risalah al-ittishal (3) risalah al-wada' (4) tadbir al-mutawahbid. Majid Fakhry dalam salah satu karyanya juga menyebutkan, di antara karya-karya logika Ibnu Bajjah adalah seri komentar dari logika al-Farabi, termasuk the Categories, the Five Section, On Interpretation (Kitab al-Ibarab), Analitica Priora (Kitab al-Qiyas) dan Analitica Posteriora (Kitab al-Burban). ${ }^{25}$

Masih banyak pemikiran Ibnu Bajjah yang tidak diketahui, karena sebagian besar karyanya telah musnah. Bagian yang tertinggal dan sampai pada kita hanya merupakan sisasisa dokumen yang berserakan di beberapa perpustakaan di Eropa. Hal ini sangat disayangkan, padahal Ibnu Tufayl telah mengatakan bahwa di antara orang-orang Andalusia tidak ada yang lebih cerdas dari Ibnu Bajjah, namun sayangnya ia telah disibukkan dengan urusan duniawi. Ia meninggal dunia sebelum sempat mengungkapkan ladang keilmuan dan menjelaskan rahasia filsafat yang dimilikinya. Sebagian besar karangannya dan terpurus bagian akhirnya, seperti kitab Fi-Nafs dan Tadbir al-Mutawabhid atau kitab-kitab lain dalam bidang mantiq dan fisika. Sementara karangannya yang sempurna hanya buku-buku ringkas dan surat-surat tersembunyi. Karya Risalab Ittish al-nya juga tidak ditulis secara jelas, karena menggunakan bahasa yang rumit dan membosankan. ${ }^{26}$ Oleh karena itu sangat sulit untuk mendeskripsikan dengan lengkap apa yang terkandung dalam tiap-tiap karyanya.

\section{Genealogi Pemikiran Ibnu Bajjah}

Ibnu Bajjah sebagai tokoh utama yang dapat dikatakan sebagai pembangun jembatan filsafat Islam di Barat itu tidak dapat diketahui banyak sejarahnya, dan tidak banyak karya yang berhasil disempurnakannya. Namun demikian, dari sekian karya orisinilnya, ia berjasa memperkenalkan filsafat Aristoteles secara mendalam. Namun, meskipun Ibnu Bajjah sangat paham karya-karya Aristoteles, ia juga terpengaruh dari para filosof muslim sebelumnya. Sebagaimana ditegaskan Ibnu Tufayl bahwa filsafat yang sampai ke tangan kita, filsafat Aristoteles dan al-Farabi, Abu Ali (Ibnu Sina) dalam kitab as-Syifa', memiliki tujuan yang sama dengan apa yang hendak dijelaskan Abu Bakar (Ibnu Bajjah). ${ }^{27}$ Di antara pendahulunya, hanya satu yang paling sering dirujuk oleh Ibnu Bajjah, yang ia anggap sebagai guru dalam bidang poitik, etika dan logika, yaitu al-Farabi, orang yang benar-benar memahami filsafat Aristoteles dan dijuluki al-Múallim al-Awwal (Guru Pertama). Bahkan Ibnu Sina, yang menyandangkan predikat al-Syaikh al-Ra'is (Guru Utama), mendapatkan kunci dalam memahami filsafat Aristoteles dari buku al-Farabi, yang berjudul fi Agradbi ma ba'da al-Thabi'at. ${ }^{28}$ Di samping al-Farabi mengembangkan emanasi yang dibawa oleh al-Kindi, ia juga menjadi masyhur karena keberhasilannya memperkenalkan doktrin "Harmonisasi pendapat Plato dan Aristoteles", dan ia memulai wawancaranya dengan gagasan Plato tentang perlunya menempatkan harmonisasi seperti itu pada landasan filsafat yang paling dasar. ${ }^{29}$ Meskipun Aristoteles menolak akal-akal Plato, al-Farabi menemukan celah dalam

\footnotetext{
${ }^{24}$ Abdul Rahman Badawi, dalam Mausuat al-Hadharoh al-'Arabiyah al-Islamiyah, h. 85-88.

${ }^{25}$ Majid Fakhry, Al-Farabi, Founder of Islamic Neoplatinosm: His Life, Works and Influence, (Oxford: Oneworld, 2002), h. 137.

${ }^{26}$ Ibnu Tufail, Hayy bin Yaqdzon, terj. Nurhidayah (Yogyakarta: Navila, 2010), h. 122.

${ }^{27}$ Ibnu Tufail, Hayy bin Yaqdzon, h. 120.

${ }^{28}$ Sirajuddin Zar, Filsafat Islam, h. 67.

${ }^{29}$ Mehdi Ha'iri Yazdi, Menghadirkan Cahaya Tuhan, h. 46.
} 
penjelasan Aristoteles ketika menggunakan terminologi "sebab pertama" dalam menjelaskan persoalan teologis. ${ }^{30}$

Ibnu Bajjah sangat terpengaruh oleh al-Farabi dalam banyak hal, sehingga dapat dikatakan bahwa filsafat politik dan etika Ibnu Bajjah sepenuhnya beraliran Farabian. Ibnu Bajjah juga masih menganut spirit emanasi, namun bentuk pemikirannya tidak banyak dipengaruhi oleh Plato, melainkan dari al-Farabi. ${ }^{31}$ Satu persamaan yang kentara antara alFarabi dan Ibnu Bajjah ialah keduanya meletakkan pemikiran bahwa ilmu mengatasi segalanya. ${ }^{32}$ Namun, berbeda dengan al-Farabi yang secara optimis membangun kota ideal dengan figur seorang filsuf sebagai citra ideal seorang pemimpin, Ibnu Bajjah di sisi lain justru bersikap pesimis dengan konstruksi sosial ideal semacam itu. Ia justru menganjurkan untuk ber-mutawahbid, yaitu semacam menjauhi realitas sosial yang tidak memungkinkan bagi para filsuf untuk dapat berkontemplasi. Ibnu Bajjah juga tidak melihat kota ideal yang dicitacitakan al-Farabi, ia justru melihat kota yang tidak ideal yang menjadi ancapan bagi filsuf untuk memperoleh kesempurnaan intelektualnya.

Menurut al-Farabi, realitas yang ada ini, dari bentuknya, terbagi dalam dua bagian: wujud-wujud spiritual (al-manjudat al-rubiyab) dan wujud-wujud material (al-manjudat almadiyah). Wujud-wujud spiritual merupakan realitas non materi yang terbagi menjadi enam tingkatan: tingkatan pertama, yaitu Tuhan sebagai Sebab Pertama (al-sabab al-awwal) yang memunculkan intelek pertama penggerak langit pertama. Tingkatan kedua adalah intelekintelek terpisah (al-uqul al-mufariqab) yang terdiri atas sembilan intelek. Tingkatan ketiga adalah intelek aktif (al-'aql al-fa'al) yang bertindak sebagai penghubung antara alam atas dan bawah, antara realitas spiritual dan realitas material. Tingkat keempat adalah jiwa manusia (alnafs al-insaniyah), sedangkan tingkatan kelima dan keenam masing-masing adalah bentuk (s'urah) dan "materi" (b ayula). H'ayula adalah materi pembentuk benda dan bersifat nonfisik, sedangkan surah adalah bentuk konkret dari b'ayula. Tiga tingkatan pertama dalam realitas spiritual merupakan wujud-wujud murni yang sama sekali tidak berkaitan dengan bentuk-bentuk material; sedangkan tiga tingkatan terakhir berhubungan dengan materi meski substansi ketiganya sendiri tidak bersifat material. ${ }^{33}$ Tingakatan-tingkatan wujud spiritual tersebut dikonversi oleh Ibnu Bajjah ke dalam wilayah yang lain, yaitu wilayah psikologis manusia, dalam arti tindakan-tindakan manusia ditentukan oleh bentu-bentuk spiritual yang mendominasinya.

Al-Farabi juga tergolong filsuf sinkretisme (pemaduan) yang percaya akan kesatuan (ketunggalan) filsafat. ${ }^{34}$ Pemaduan dan kesatuan ini juga dipakai Ibnu Bajjah untuk menjelaskan realitas orang-orang penyendiri (mutawabhid). Dalam karya besarnya Tadbir alMutawahbid, ia menggambarkan "seorang penyendiri", atau seorang filsuf sebenarnya (genuine philosopher), sebagai orang yang mencari keterhubungan (ittis'al) dengan Akal Aktif (Active Intellect). ${ }^{35}$ Istilah ini juga dimabil dari al-Farabi untuk digunakan sebagai entitas spiritual yang harus dicapai manusia untuk mendapatkan kebahagiaan puncak. Al-Farabi meyakini bahwa setiap manusia sesungguhnya mempunyai "watak bawaan tertentu" yang siap meneria bentuk-bentuk pengetahuan yang disebut intelek potensial (al'aql bi al-qumwab). Intelek ini berisi potensi-potensi yang akan mengabstraksikan bentuk-bentuk pengetahuan yang diserapnya setelah meningkat menjadi intelek aktual (al-'aql bi al-fi'). Namun, proses abstraksi dari intelek potensial itu sendiri tidak akan terjadi kecuali ada "cahaya" dari intelek

\footnotetext{
${ }^{30}$ Mehdi Ha'iri Yazdi, Menghadirkan Cahaya Tuban, h. 325.

${ }^{31}$ Abdul Rahman Badawi, dalam Mausuat al-Hadharoh al-'Arabiyah al-Islamiyah, h. 104.

${ }^{32}$ Wahyu Murtiningsih, Para Filsuf dari Plato Sampai Ibnu Bajjah, h. 336.

${ }^{33}$ A. Khudori Soleh, Filsafat Islam: Dari Klasik. Hingga Kontemporer, (Yogyakarta: Ar-Ruzz Media, 2013), h. 114115.

${ }^{34}$ Wahyu Murtiningsih, Para Filsuf dari Plato Sampai Ibnu Bajjah, h. 246.

${ }^{35}$ Majid Fakhry, Al-Farabi, Founder of Islamic Neoplatinosm, h. 137.
} 
aktif. ${ }^{36}$ Seorang sufi dan filosof, secara khusus setuju dengan dengan pandangan ini, yang dapat disebut sebagai a philosopico-ethical program of salvation (program filsafat-etika untuk keselamatan) bagi jiwa untuk mengambil bagian dari kondisi keterhubungannya dengan Akal Aktif dalam kehidupan. Seorang sufi menekankan pada aspek praktis dan personal dari program ini dan menunjukkan puncak tanggah penyatuan, sedangkan seorang filosof menekankan aspek teoritis dan spekuatifnya dan disebut sebagai keterhubungan (conjunction atau ittis ${ }^{\prime}$ al). ${ }^{37}$

Filsafat Ibnu Bajjah memang belum mencapai kata sempurna, karya-karyanya yang juga belum dapat dianggap sebagai karya yang utuh, namun hasil pemikiran Ibnu Bajjah memiliki pengaruh besar pada Ibnu Rusyd. Satu-satunya pendahulu Ibnu Rusyd yang disebutukan namanya dan yang ia segani adalah Ibnu Bajjah, orang yang mengenalkan studi Aristoteles di Andalusia. Di samping itu, ia juga memiliki pengaruh terhadap Albert the Great dan juga beberapa filosof Yahudi. ${ }^{38}$ Maimonides juga sangat mengagumi Ibnu Bajjah, yang mengutip komentarnya atas Physics Aristoteles, dengan mengikuti jejaknya dalam Astronomi, epistemologi, dan metafisika jiwa. Dalam surat terkenalnya kepada penerjemah bahasa Ibrani dari The Guide of The Perplexed yang berbahasa Arab, ia menyebut Ibnu Bajjah sebagai seorang filosof besar dan menaruh semua tulisannya pada peringkat pertama. ${ }^{39}$ Sehingga tidak berlebihan ketika mengatakan bahwa jika ingin mengetahui dasar filsafat Islam di Barat, maka yang menjadi dasar pijakannya adalah Ibnu Bajjah, yang kemudian banyak mengilhami Ibnu Rusyd yang dianggap sebagai orang yang mengukuhkan filsafat Islam di Barat sebagai filsafat demonstratif (al-burban).

\section{Jiwa dan Pengaruhnya Terhadap Tindakan Mutawahhid}

Ibnu Bajjah membagi dua bidang keilmuan yang dimasukkannya ke dalam pembahasan filsafat, yaitu ilmu jiwa ('ilm an-nafs) dan ilmu alam ('ilm at-thabi' '). Sedangkan untuk ilmu ketuhana atau teologi, ia tidak membahasnya secara khusus, kecuali hanya sebatas statemen-statemen dalam Risalat al-Wada' dan Ittis 'al al-Insan bi al-'Aql al-Fa' $a l^{40}$ Dalam memulai kajiannya tentang jiwa, Ibnu Bajjah membedakan segala bentuk-bentuk materi dengan "yang alami" dan "yang buatan". Tubuh alami dicontohkan seperti batu, sementara yang buatan seperti meja, kursi, dan lain sebagainya. Dari pembagian mengenai tubuh tersebut ia menjelaskan perbedaannya dari sudut pandang gerak. Tubuh yang alami (natural body) memiliki penggerak mereka di dalam seluruh tubuh, sehingga tubuh yang natural terdiri dari penggerak dan gerakan. Sedangkan tubuh buatan (artifisial body) memiliki penggeraknya di luar, yaitu sesuatu yang digerakkan, dan sesuatu yang digerakkan terhubung dengan penggerak secara tidak sengaja. ${ }^{41}$

Di sisi lain, dilihat dari jenis segala sesuatu, tubuh atau benda-benda juga dapat dibagi menjadi "yang bergerak" dan "yang tidak bergerak". Sesuatu yang bergerak selalu merupakan sesuatu yang memiliki tubuh alamiah, sementara yang tidak bergerak diyakini sebagai spirit, tempat di mana substansi jiwa bersemayam menjadi pergerakan itu sendiri. ${ }^{42}$ Ibnu Bajjah tidak menjelaskan tentang sesuatu "yang tidak bergerak" dalam kajiannya tentang jiwa. Ia juga memasukkan pembagian yang lain dalam kajian ilm an-nafs. Ia menjelaskan sesuatu yang bergerak adakalanya secara esensi dan secara aksiden, karena bisa

\footnotetext{
${ }^{36}$ A. Khudori Soleh, Filsafat Islam: Dari Klasik. Hingga Kontemporer, h. 129.

${ }^{37}$ Majid Fakhry, A History of Islamic Philosophy, h. 261.

${ }^{38}$ Seyyed Hossein Nasr dan William C. Chittick, Islam Intelektual: Teologi, Filsafat, dan Ma'rifat, terj. Tim Perenial (Depok: Perenial Press, 2001), cet. III, h. 72.

${ }^{39}$ Seyyed Hossein Nasr dan Oliver Leaman (ed.), Ensiklopedi Tematis Filsafat Islam, h. 368.

${ }^{40}$ Abdul Rahman Badawi, dalam Mausuat al-Hadharoh al-'Arabiyah al-Islamiyah, h. 89.

${ }^{41}$ Ibnu Bajjah, Ilm al-Nafs, (Karachi: Pakistan Historical Society, 1956), h. 16.

${ }^{42}$ T. J. De Boer, The History of Philosophy in Islam, h. 178.
} 
jadi hal itu bergerak dengan sendiri, atau bergerak melalui instrumen. Pendapat ini kemungkinan menjadi penjelasan tentang Tuhan yang tidak bergerak dalam kaitannya dengan proses penciptaan, atau merupakan konsep Penggerak Utama (causa prima) yang diambil dari Aristoteles. Ibnu Bajjah tidak terlalu tertarik untuk menjelaskan teori emanasi sebagaimana pendahulunya al-Farabi, akan tetapi secara tersirat susunan-susunan jiwa dan spiritualitas seakan terbentuk dari susunan emanasi di mana oleh Ibnu Bajjah digunakan sebagai jalan naik menuju keterhubungan dengan Akal Aktif (al-'Aql al-Fa'al). Di sinilah sebenarnya ia melangkah sedikit lebih maju dalam menjelaskan proses psikologis keterhubungan antara yang alamiah dengan yang ilahiah melalui susunan emanasi tersebut.

Hubungan dua entitas yang berbeda itu, antara yang alamiah dan yang ilahiah, juga tampak dalam penjelasan mengenai tubuh alamiah yang digerakkan melalui perantara dari luar yang bersifat immateri. Pergerakan tubuh semacam itu, bagi Ibnu Bajjah, juga dimediasi oleh bentuk spiritual yang tidak bergerak. Bentuk-bentuk spiritual itu dibagi menjadi empat macam: (1) benda-benda angkasa, (2) akal aktif (al-'Aql al-Fa'al) dan akal perolehan (al-'aql almustafad), (3) materi yang dapat dicerna akal (intelligible), (4) konsep-konsep yang muncul dalam ruang-ruang yang berbeda dalam jiwa, seperti dalam ruang imajinasi, dan daya ingatan. ${ }^{43}$ Bentuk pertama bukan merupakan materi sama sekai, sedangkan bentuk ketiga (materi intelligible) selalu berhubungan dengan materi dan dianggap materi karena tersusun dari material intelligibles. Bentuk yang kedua (akal aktif dan akal perolehan) adalah murni nonmaterial. Akan tetapi bentuk ini memiliki hubungan dengan materi karena ia menyempurnakan material intelligibles sebagaimana dalam kasus intellectus acquisitus (al-'aql almustafad), atau karena ia yang menciptakan material intelligibles tersebut seperti dalam kasus Akal Aktif (al-'aql al-fa'al). Sedangkan bentuk yang keempat berada di antara material intelligibles dan spiritual forms (al-ma'qulat al-bayulaniyat dan as-shuwar al-rubaniyat). Seperti bentuk-bentuk materil, tipe keempat ini dinaikkan ke tingkat spiritual melalui fugsi abstraksi yang terdapat dalam jiwa manusia. Puncak dari fungsi abstraksi ini adalah pemikiran rasional. ${ }^{44}$ Bentuk-bentuk spiritual tersebut menurut al-Jabiri adalah presepsi-presepsi, pikiran-pikiran, atau makna-makna yang menggerakkan manusia untuk bertindak. ${ }^{45}$

Jiwa, di pihak lain, terhubungan dengan bentuk-bentuk spiritual untuk mengantarkan tindakan-tindakan manusia menjadi bermakna. Jiwa ini terbagi menjadi beberapa bidang, yang dapat disederhanakan menjadi empat bagian. Pertama, nutritive faculty, yaitu semacam bidang dalam jiwa yang berfungsi untuk menggerakkan proses pertumbuhan dan reproduksi bagi manusia. Kedua, the faculties of sense-perception, di mana terdapat lima panca indera, dan di atasi oleh apa yang ia namakan sebagai common sense, yang menyempurnakan hasil proyeksi semua panca indera menjadi satu konsep yang utuh. Seperti konsepsi tentang "bunga mawar", yang memiliki proyeksi indera penglihatan sebagai "merah", indera penciuman sebagai "wangi", dan indera peraba sebagai "berduri", dan lain sebagainya, sehingga presepsi tentang "bunga mawar" sama sekali berbeda. Ketiga, the faculty of imagination, tempat di mana bentuk-bentuk tertinggi dari segala yang dapat diindera menjadi dipahami. Keempat, the reasoning faculty, tempat di mana segala hal memiliki maknanya. Keterhubungan jiwa manusia dengan bentuk-bentuk spiritual dengan demikian memberikan tantangan berbeda bagi para filsuf dengan tantangan yang diupayakan oleh kalangan sufi. Tujuannya adalah mencapai pengetahuan universal yang ditandai dengan keterhubungan jiwa dengan Akal Aktif yang mentransformasi manusia ke dalam keabadian Akal Perolehan. Di sinilah, bagi Ibnu Bajjah, dapat dicapai kesempurnaan intelektual yang bersifat spiritual murni.

\footnotetext{
${ }^{43}$ Ibnu Bajjah, Tadbir Al-Mutawabid, (Tunisia: Ceres Edition, 1994), h. 21.

${ }^{44}$ Majid Fakhry, Sejarah Filsafat Islam: Sebuah Peta Kronologis, terj. Zaimul Am (Bandung: Mizan, 2002), h. 101102.

${ }^{45}$ Muhammad Abid al-Jabiri, Nahnu wa at-Turats, h. 186-187.
} 
Ibnu Bajjah meyakini, bahwa manusia harus mampu memproyeksikan semua maknamakna partikular menuju jiwa rasional melalui imajinasi untuk dapat menemukan makna universalnya. ${ }^{46}$ Imajinasi, sebelum memberikan makna rasional, ia memproyeksikan satu objek dengan objek yang lain yang lebih tinggi dalam ruang yang disebut dengan representasi. Hasil representasi memang diyakini tidak memiliki jaminan kebenaran sehingga ia benar-benar merujuk kepada apa yang sudah pernah diproyeksikan dalam sense-perception. Hal ini berbeda dengan bidang rasional jiwa, bahwa makna-makna yang dicerna oleh imajinasi adalah makna partikular, sementara bidang rasional menerima makna-makna unniversal. ${ }^{47}$ Transformassi makna partikular menjadi universal dengan demikian adalah suatu analogi makna, atau seperti yang Abdul Rahman Badawi sebutkan sebagai al-'Azm wa at-Tas'mim (ketentuan dan tekad) dari segala perbuatan manusia. Sehingga gerakan jiwa tersebut diciptakan dari daya imajinasi dan hasrat. Imajinasi adalah gerakan, dan penggeraknya adalah hasrat. ${ }^{48}$

Manusia diyaikini menjadi sempurna secara psikologis melalui kegiatan semacam ini, yaitu mengoptimalkan fungsi-fungsi jiwanya sendiri, yaitu dengan menyatukan ketiga fakultas (indera persepsi, fakultas imajinasi, daya ingat) di mana ketiganya menyetujui suatu tindakan, akan melahirkan sesuatu yang luar biasa dalam penyatuannya. ${ }^{49}$ Berbeda dengan kalangan sufi yang membuat metode olah jiwa (tazkiyat an-nafs) yang bertujuan pada aplikasi tindakan moral, sementara filosof, sebagaimana diyakini Ibnu Bajjah, mengoptimalkan jiwanya untuk mendapatkan makna-makna universal dan dengan demikian bersifat spiritual. Orang-orang sufi mengatakan bahwa pergerakan jiwa yang akan mengantarkan manusia kepada tujuan akhirnya adalah semacam intuisi atau kontemplasi spiritual, sementara para filosof mengatakan bahwa pergerakan jiwa tersebut tidak lain adalah pemikiran murni yang membantu manusia mendapatkan pencerahan jiwa dari atas. ${ }^{50}$

Menurut Ibnu Bajjah, setiap tindakan manusia, bila dilihat dari jiwanya, maka tindakan-tindakan tersebut dapat dikategorikan ke dalam tiga bentuk: (1) ada kalanya tindakan tersebut hanya berbentuk jasmaniah saja. (2) ada kalanya tindakan tersebut lahir dari spiritual partikular, dan ini terbagi menjadi: pertama, bentuk jiwa yang terdapat dalam indera persepsi; kedua, bentuk jiwa dalam imajinasi; ketiga, bentuk jiwa yang sempurna yang ada dalam daya ingat. (3) tindakan yang dihasilkan dari spiritualitas universal, ini adalah bentuk sempurna jiwa yang menunjukkan perpaudannya antara jasad dan ruh mutlak. ${ }^{51}$ Dengan alasan tersebut Ibnu Bajjah menegaskan, bahwa orang-orang yang tindakannya hanya bergantung pada materi adalah keji dan hina, sedangkan mereka yang tindakannya bergantung pada jiwa atau spiritualitas adalah orang-orang yang unggul dan mulia. ${ }^{52}$ Dalam mengantarkan manusia menuju pencapaiannya dengan akal aktif sehingga menjadi manusia yang unggul dan mulia, tiga bentuk tindakan tersebut dapat dianggap sebagai tahapantahapan yang harus dilalui untuk mencapai kesempurnaan, yaitu: ${ }^{53}$ (1) Tahapan mayoritas, yaitu yang hanya sampai pada pengetahuan tentang materi. (2) Tahapan orang berilmu. (3) Tahapan orang-orang yang bahagia yang mengetahui sesuatu dengan sendirinya, mereka adalah para fiosof dalam arti yang sebenarnya.

\footnotetext{
${ }^{46} \mathrm{Ibnu}$ Bajjah, Tlm al-Nafs, h. 106.

${ }^{47}$ Ibnu Bajjah, Ilm al-Nafs, h. 120.

${ }^{48}$ Abdul Rahman Badawi, Mausuat al-Hadharoh al-'Arabiyah al-Islamiyah, h. 95-96.

${ }^{49}$ Ibnu Bajjah, Tadbir Al-Mutawabid, h. 29.

${ }^{50}$ Lihat T.J. De Boer, The History of Pholosophy in Islam, h. 179.

${ }^{51}$ Ibnu Bajjah, Tadbir Al-Mutawahid, h. 39-47.

${ }^{52}$ Ibnu Bajjah, Tadbir Al-Mutawabid, h. 61.

${ }^{53}$ Lihat Muhammad Abid al-Jabiri, Nahnu wa at-Turats, h. 198. Lihat juga Abdul Rahman Badawi, Mausuat alHadharoh al-'Arabiyah al-Islamiyah, h. 97-98.
} 


\section{Pesimisme Eksistensial Para Penyendiri}

Seperti al-Farabi dan Ibnu Sina, persoalan filsafat Ibnu Bajjah adalah persoalan etis dan eskatologis. Pemikiran filsafatnya sebagaimana ditunjukkan dalam istilah Ibnu Sina sebagai "keterhubungan" (ittis'al) dengan Akal Aktif, adalah kondisi pencapaian intelektual atau spiritual di mana pikiran telah menyatu dengan Yang Maha Mengetahui. ${ }^{54}$ Kebahagian, bagi kebanyakan filsuf, adalah harapan puncak dari pencapaiannya dengan Akal Aktif tersebut. Ibnu Bajjah juga meyakini demikian, ia banyak merujuk kepada etika Aristoteles yang tertuang dalam Nicomachean Ethics. Aristoteles mengatakan bahwa jika yang baik menjadi tujuan, maka kebahagiaan adalah yang paling baik, paling mulia, dan paling menyenangkan sekaligus. ${ }^{55}$ Ibnu Bajjah dengan alur yang berbeda, meyakini bahwa kebaikan, yaitu kebahagiaan itu sendiri, adalah makna-makna universal yang didapatkan dalam kondisi keterhubungan dengan Akal Aktif dan Akal Perolehan. Dengan menyematkan sifat spiritualitas ketuhanan pada Akal Perolehan maka secara tidak langsung kebahagian itu sendiri bersifat spiritual murni.

Akan tetapi di sisi lain, Ibnu Bajjah, sebagaimana pendahulunya yaitu al-Farabi, juga mengupayakan terbentuknya kota sempurna yang oleh Ibnu Bajjah disebut dengan almadinah al-kamilah. Namun tidak seperti al-Farabi, ia menggambarkan kota sempurna dapat diwujudkan bukan oleh transformasi eksternal, reformasi, ataupun revolusi, tetapi oleh transformasi internal (inner transformation) dari individu-individu yang telah menyatu dengan Akal Aktif (Active Intellect atau al-'aql al-fa'al) dan dapat mengaplikasikannya dengan sempurna. Individu-individu ini adalah figur-figur yang menyendiri, aneh, dan terasingkan (solitary figures, strangers, and exiles) dalam dunia yang terdiri dari manusia-manusia yang tidak dapat menampilkan pandangan tentang dunia yang benar-benar dapat dipahami. ${ }^{56}$

Dari sudut pandang yang lain, apa yang diupayakan oleh Ibnu Bajjah berhubungan dengan orang-orang penyendiri (mutawahbid) sebagai pihak kunci yang memiliki konsepsi universal tentang bagaimana kota sempurna itu harus dibangun adalah semacam tahapan psikologis manusia menuju kematangan dan kedewasaan berpikir. Mereka yang masih bertindak dengan pengaruh makna-makna materil tentu tidak dapat dikatakan sebagai manusia dewasa, sehingga tentu tidak akan mampu merubah keadaan di luar dirinya sebelum ia merubah keadaan internalnya terlebih dahulu. Sebalinya, manusia dewasa, yang bagi Ibnu Bajjah dianggap telah mencapai Akal Aktif, terhubungan dengan makna-makna universal dan spiritual, mencapai kebahagiaan hakiki, adalah mereka yang sudah mencapai kesempurnaan dalam internal dirinya, sehingga ia mengetahui tentang bagaimana merubah keadaan dengan makna-makna universal dan kebaikan spiritualnya, dan memberikan kebahagiaan hakiki pada tingkat sosial. Ibnu Bajjah dalam Tadbir al-Mutawabhid-nya jelas hendak menyampaikan transformasi psikologis itu. Ia bahkan menjelaskan, segala sesuatu yang lahir dari akal aktif adalah benar secara esensinya, bukan aksidensinya. Oleh karena itu, segala yang hadir dalam pemikiran itu benar. ${ }^{57}$ Para penyendiri (mutawabbid), dengan demikian perlu untuk melakukan transformasi sosial setelah ia mencapai transformasi individual.

Seorang filsuf eksistensialis Barat, dengan model yang agak mirip, juga menjelaskan tahap-tahap eksistensi manusia dengan tangga vertikal yang bernilai spiritual. Soren Kierkegaard membagi tahapan eksistensi mansusia ke dalam tiga tahapan, yaitu tahap estetik, tahap etik dan tahap religius. ${ }^{58}$ Sama dengan Ibnu Bajjah, tahapan eksistensi Kierkegaard juga menandakan tahap-tahap psikologis manusia di mana setiap tahapan menunjukkan

\footnotetext{
${ }^{54}$ Majid Fakhry, A History of Islamic Philosophy, h. 261.

${ }^{55}$ Aristoteles, Nicomachean Ethics: Sebuah “Kitab Suci” Etika, terj. Embun Kenyowati (Jakarta: Teraju, 2004), h. 18.

${ }^{56}$ Seyyed Hossein Nasr, Islamic Philosophy from Its Origin to The Present, h. 152.

${ }^{57}$ Ibnu Bajjah, Tadbir Al-Mutawabid, h. 75.

${ }^{58}$ Bernard Delfgaauw, Sejarah Ringkas Filsafat Barat, terj. Soejono soemargono (Yogyakarta: Tiara Wacana, 1992), h. 152.
} 
bentuk pola pikir dan pencapaian yang lebih tinggi. Ia mengatakan bahwa "manusia pada tahap estetik adalah manusia aksidental". ${ }^{9}$ Tahapan yang dinilai sangat rendah dan tidak memiliki kualitas universal sama sekali. Dalam tahapan ini, yang ada hanyalah kesenangan, hasrat, dan tujuan temporal material semata sebagai pendorong eksistensi manusia. Sikap hedonis adalah tindakan eksistensi manusia pada tahap ini, sampai manusia mencapai tahap kedua, tahap etis, yaitu tahap ketika manusia sudah mulai memahami makna-makna universal yang menuntun kehidupannya, sehingga pada tahap ini terdapat nilai-nilai moral yang dijunjung bersama.

Tahap etis, dinilai lebih baik dari tahap estetis. Dalam makna yang lain dapat dikatakan bahwa etika atau moral, lebih baik dan lebih tinggi nilainya dari sekedar estetis, yaitu kesenangan abstrak dalam benda-benda material. Moralitas tidak bersemayam dalam bendabenda material, akan tetapi melingkupi kesadaran manusia. Namun demikian, moralitas tidak setinggi nilainya dibandingkan religius. Di sinilah Kierkegaard menempatkan puncak eksistensi manusia. Tahap ketiga, manurut Kierkegaard adalah tahap di mana manusia tampil dengan kesejatihannya, sebagai pribadi yang tunggal menghadap Tuhan. ${ }^{60}$ Suatu pandangan yang sangat mirip dengan konsep "kemanunggalan" yang disebut Ibnu Bajjah dengan konsep ittis'al, yaitu konsep puncak eksistensi di mana manka-makna universal digapai dan kebahagiaan sejati melingkupi eksistensi. Seperti yang dijelaskan oleh al-Jabiri bahwa tujuan akhir kemanusiaan dan kebahagiaan tertinggi (as-sa'adah al-kamilab) adalah satu kesatuan, yaitu puncak intelektualitas yang terjadi melalui penyatuan dengan akal aktif yang menyingkapkan akal perolehan. ${ }^{61}$

Konsep ittis al Ibnu Bajjah, sebagai puncak eksistensi manusia, sebenarnya masih bermuatan kontroversi. Sama dengan konsep penyatuan (ittihad) bagi para pelaku mistis, bahwa beberapa kelompok menegaskan ittis'al mungkin dilakukan dan mereka memetakan program-program terperinci untuk mewujudkannya, sementara sebagian orang lain sangat keberatan dengan konsep ini. ${ }^{62}$ Ungkapan ini merepresentasikan dua cara di mana penyatuan dengan Tuhan telah digambarkan oleh Sufi: ittis al sebagai kontak, persekutuan, atau serikat pekerja; dan ittib ad, sebagai sebuah identifikasi dari sifat. Para filosof menggunakan istilah ini untuk menatakan penyatuan hubungan. Namun kecerdasan pasif manusia bukan menyatu dengan Tuhan, tetapi dengan Akal Aktif, sehingga menjadi pemahaman yang sepenuhnya diaktualisasikan, mengetahui semua bahwa adalah mungkin bagi pikiran manusia untuk tahu. ${ }^{63}$ Al-Jabiri, menggambarkan keterhubungan manusia penyendiri (mutawabhid) sebagai berikut: ${ }^{64}$

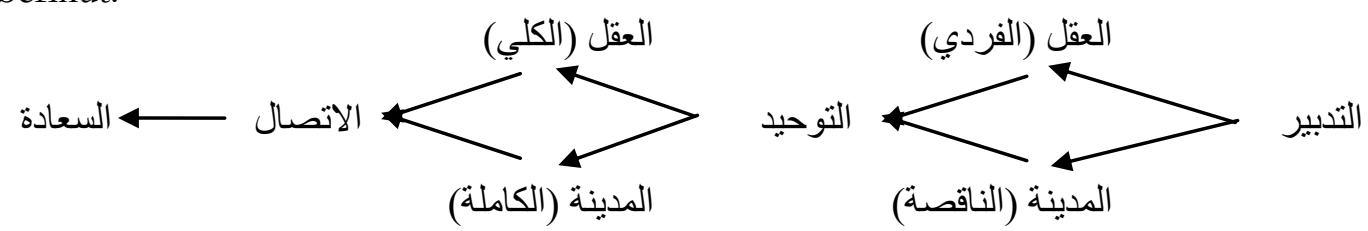

Bagi Ibnu Bajjah, seorang filosof sudah seharusnya memperbanyak tindakannya dengan tindakan spiritual, bukan dalam arti spiritualitas religius sebagaimana para sufi, akan tetapi melakukan tindakan-tindakan rasionalitas murni sebagaimana para filsuf. Mereka bereksistensi dengan tindakan jasmaniahnya, mereka mulia dengan tindakan spiritualitasnya,

\footnotetext{
59 Soren kierkegaard, Either/Or, terj. George L. Strengren, (New York: Harper and Row Publisher, 1986), h. 208.

${ }^{60}$ Fuad Hasan, Berkenalan Dengan Eksistensialisme, (Jakarta: Pustaka Jaya, 1992), h. 27.

${ }^{61}$ Muhammad Abid al-Jabiri, Nahnu wa at-Turats, h. 197.

${ }^{62}$ Diana Lobel, Between Mysticism and Philosophy: Sufi Language of Religious Experience in Judah Ha-Levi's Kuzari, (New York: State University of New York, 2000), h. 21.

${ }_{63}$ Diana Lobel, Between Mysticism and Philosophy, h. 23.

${ }^{64}$ Muhammad Abid al-Jabiri, Nahnu wa at-Turats, h. 189.
} 
dan dengan rasionalitasnya mereka memperoleh derajat ketuhanan. ${ }^{65}$ Manusia peyendiri, bahwa dalam keterhubungannya dengan Akal Aktif, di samping mereka mencapai kebahagiaan hakiki, juga mengalami keabadian kebahagiaan. Hal ini adalah implikasi logis dari konsepsi Akal Perolehan (al-'aql al-mustafad) yang bagi Ibnu Bajjah bersifat ketuhanan. Al-Jabiri mengkritik kondisi demikian dan menganggapnya sebagai suatu yang tidak mungkin. Ketika mengatakan bahwa kebahagiaan dalam penyatuan dengan akal aktif bukanlah suatu kondisi yang partikular, hal itu sama halnya dengan menganggap bahwa kebahagiaan puncak itu bersifat abadi. ${ }^{66}$ Hal tersebut sama dengan keyakinan mistis yakni semacam kebahagiaan surgawi yang didapatkan dalam keadaan bersatu dengan Tuhan dapat dirasakan di dunia materi.

Implikasi selannjutnya dari keabadian kebahagiaan yang didapatkan dalam keterhubungan (ittis`al) adalah sebuah sikap merendahkan dunia itu sendiri. Ibnu Bajjah, sekalipun mengandaikan tahapan-tahapan eksistensi psikologis menuju kesempurnaan manusia yang lebih mulia, kenyataannya ia lebih memilih untuk mengandaikan proses keterhubungan itu didapatkan dari kondisi mutawahbid. Sebuah kondisi yang diyakini sebagai puncak spiritual dalam diri seseorang yang hidup di lingkungan sosial yang tidak sehat. Sikap demikian ini seakan menggambarkan sikap pesimistis dan kontradiktif, di mana ketika kedewasaan seseorang didapatkan, ia justru tidak memiliki kemampuan untuk mendewasakan yang lainnya. Dalam ungkapan Aristoteles dijelaskan, yang baik dari manusia, kebahagiaan, adalah semacam kegiatan jiwa dalam kesesuaiannya dalam kebajikan. ${ }^{67}$ Namun bagi Ibnu Bajjah, kebajikan tersebut bersifat individual. Ia mengatakan, jika pun orang-orang yang berbahagia itu mungkin ada di negara-negara yang demikian, kebahagiaan mereka tentunya hanyalah kebahagiaan pribadi semata (mufrad), dan jenis kekuasaan yang benar dalam keadaan demikian juga bersifat pribadi, apakah yang bersangkutan itu individu atau kelompok. ${ }^{68}$

Dalam filsafat Arthur Schopenhauer, suatu kebaikan dan kemuliaan justru bisa didapatkan dari pelarian dari dunia dan kehendak untuk hidup, suatu sikap pesimistis yang hampir sama dengan Ibnu Bajjah. Pierre Teilhard de Chardin mengungkapkan, bahwa setidaknya ada tiga tipe sikap manusia menjalani hidupnya, sebagaimana diungkapkan oleh Fransiskus Borgias M dalam Manusia Pengembara; ${ }^{69}$ pertama, sikap menggairahkan yakni memandang kehidupan ini sebagai suatu perspektif yang selalu memberikan harapan, peluang, dan kemungkinan-kemungkinan baru yang lebih cerah kepada manusia. Kedua, sikap menikmati berarti memandang kehidupan ini sebagai kesempatan untuk menikmati apa saja sampai sepuas-puasnya. Ketiga, sikap kebosanan (membosankan) berarti memandang kehidupan ini terutama sebagai kesuraman, frustasi atau bencana besar (absurd, tanpa makna). Sikap seperti ini menyebabkan orang pesimistis, lesu, serta tanpa harapan dan gairah sama sekali dalam memandang dan menilai kehidupan ini. Ibnu Bajjah, sekalipun tidak secara eksplisit merendahkan dunia, ia menempatkan orang-orang mutawabhid pada posisi yang pesimistis terhadap kondisi sosial. Menganggap orang mutawahhid sebagai orang-orang bijak yang hidup di negara yang rusak sebagai "tumbuhan liar" (nawabit) sama halnya dengan mengatakan bahwa mereka tidak dapat berbuat apa-apa selain memandang rendah lingkungannya sembari menikmati kebahagiaan pribadinya.

Nada yang sama juga diutarakan oleh Schopenhauer, sebagaimana dijelaskan oleh Bertens, bahwa hidup sebagai manusia selalu berarti juga mengalami kesengsaraan. Namun demikian, ada dua jalan untuk mengatasi keadaan itu: jalan estetis dan jalan etis. Jalan

\footnotetext{
${ }^{65} \mathrm{Ibnu}$ Bajjah, Tadbir Al-Mutawabid, h. 62-63.

${ }^{66}$ Lihat Muhammad Abid al-Jabiri, Nabnu wa at-Turats, h. 197.

${ }^{67}$ Aristoteles, Nicomachean Etbics, h. 19.

${ }^{68}$ Seyyed Hossein Nasr dan Oliver Leaman (ed.), Ensiklopedi Tematis Filsafat Islam, h. 387.

${ }^{69}$ Fransiskus Borgias, Manusia Pengembara: Refleksi Filosofis Tentang Manusia, (Yogyakarta: Jalasutra, 2013), h. 5758.
} 
pertama adalah kesenian, khususnya musik. Tetapi kesenian membuat kita melupakan kesengsaraan untuk sementara saja. Yang lebih efektif adalah jalan kedua. Di sini secara radikal manusia memadamkan segala hawa nafsu dan melepaskan diri dari setiap macam keinginan. Dengan demikian ia dapat mencapai "Nirwana", istilah yang dipinjam Schopenhauer dari agama Buddha. ${ }^{70}$ Jalan yang kedua adalah jalan terbaik menuju pembebasan. Karena penyebab penderitaan adalah intensitas kehendak; semakin kurang kita memberi ruang bagi kehendak, semakin kurang kita menderita. ${ }^{71}$ Ibnu Bajjah, dengan nada yang sama, melihat jalan terbaik menuju kebahagiaan hakiki adalah dengan berhubungan dengan Akal Aktif, hanya saja karena keterhubungan ini hanya bersifat individu, maka pribadi-pribadi yang sudah mengalami ittis al secara tidak langsung adalah pribadi yang mencoba lari dari dunia untuk mencari kebaikan yang diyakini bersifat transenden. Schopenhauer mengatakan, atas dasar kehendak untuk hidup, Egoisme tumbuh, dan seperti parit yang luas membentuk pemisahan abadi antara manusia dan manusia. ${ }^{72}$ Akibatnya, nilai moral suatu tindakan diturunkan oleh pengungkapan seperangkat dorongan egois. ${ }^{73}$

Kesempurnaan spiritual yang diandaikan Ibnu Bajjah dalam pribadi mutawahbid, dalam sudut pandang yang sedemikian pesimis menjadi semacam bentuk lain dari konsep kehendak Schopenhauer. Ibnu Bajjah, sebagaimana para filsuf lain, mengandaikan puncak spiritual itu bisa dicapai melalui ittis'al, dan hasrat serta kehendak manusia harus diarahkan melalui jalan penyendirian. Sementara Schopenhauer, dengan alasan bahwa ide lahir dari "keinginankeinginan", mulai dari harapan yang paling halus dan tersembunyi hingga nafsu yang kuat dan mendesak, yang ia namakan sebagai "kehendak". ${ }^{74}$ Maka untuk mencapai puncak eksistensi adalah justru dengan membunuh kehendaknya atau hasratnya terhadap dunia. Kehendak adalah kategori metafisik yang mendasar, akar dari segala yang kita anggap "nyata". ${ }^{75}$ Dalam artian bahwa segala yang dianggap sebagai "hakiki" di dunia ini adalah sebuah kesalahan besar. Ia sebenarnya mencoba untuk membangkitkan kembali idealisme Plato, dengan memandang rendah dunia materi dan mengunggulkan ide abstrak transenden. Ibnu Bajjah di pihak lain sebenarnya Aristotelian, kecuali dalam pandangannya tentang keterhubungan. Moralitas Ibnu Bajjah adalah eudemonisme Yunani, yaitu kebijaksanaan unggul yang menjelma kebahagiaan. Namun moralitas demikian itu terperangkap dalam Republik Plato, sehingga kebijaksanaannya yang unggul, alih-alih sebagai puncak kedewasaan, adalah pelepasan sisi dunia dari kehidupan sosial.

\section{Simpulan}

Filsafat Ibnu Bajjah adalah bentuk filsafat yang tidak tuntas. Ia juga memperlihatkan suatu usaha yang sangat bahwa pemikiran seharusnya independen dan tidak terpengaruh oleh lingkungannya. Sebaliknya, pemikiran seharusnya dapat mempengaruhi realitas sosial. Namun sangat disayangkan, kecemerlangan Ibnu Bajjah harus berhadapan dengan kondisi psikologisnya sendiri yang belum sepenuhnya mampu untuk keluar dari gemerlap dunia materi, sehingga filsafat mutawahbid seakan-akan menunjukkan hasrat intelektualnya yang terpendam dan tidak tersampaikan. Sekalipun begitu, berbeda dengan pembacaan terhadap Ibnu Bajjah pada umumnya, dalam hal ini konsepsi mutawabhid justru dapat dilhat sebagai proses psikologis manusia meuju kedewasaan berpikir. Bagaimana manusia mengatur

\footnotetext{
${ }^{70}$ K. Bertens, Ringkasan Sejarah Filsafat, (Yogyakarta: Kanisius, 2011), h. 77.

${ }^{71}$ Betrand Russell, Sejarah Filsafat Barat, terj. Sigit Jatmiko (Yogyakarta: Pustaka Pelajar, 2007), cet. III, h. 984.

${ }^{72}$ Arthur Schopenhauer, The Basis of Morality: Second Edition, terj. Arthur Brodrick Bullock (Londoh: George Allen \& Unwin, 1915), h. 153.

${ }^{73}$ Arthur Schopenhauer, The Basis of Morality: Second Edition, h. 163.

${ }^{74}$ Simon Petrus L. Tjahjadi, Petualangan Intelektual: Konfrontasi Dengan Para Filsuf dari Zaman Yunani Hingga Zaman Modern, (Yogyakarta: Kanisius, 2004), h. 331.

${ }^{75}$ Henry D. Aiken, Abad Ideologi, terj. Sigit Djatmiko (Yogyakarta: Bentang Budaya, 2002), h. 117.
} 
tindakannya, baik tindakan fisik maupun mental, melalui pertimbangan-pertimbangan akal universal yang lebih tinggi, tidak semata-mata melalui ukuran makna material partikular atau hasrat keduniaan yang temporal, di mana pertimbangan-pertimbangan tersebut dapat dicapai melalui keterhubungan dengan Akal Aktif (al-'aql al-fa'al) yang menyingkapkan Akal Perolehan (al-aql al-mustafad). Sebagai sebuah proses pendewasaan intelektual, kondisi penyatuan juga seharusnya menyempurnakan tindakan-tindakan yang berdampak pada kalangan luas, tidak hanya memperbaiki diri sendiri, di sinilah Ibnu Bajjah tidak mampu memberikan jaminan perbaikan tersebut. Namun demikian, sekalipun filsafat Ibnu Bajjah tetap dianggap belum selesai, hasil dari usaha intelektualnya tetap perlu untuk diapresiasi sebagai sebuah pengingat bahwa filsafat (berpikir fiosofis) mampu bersikap independen dan memberikan pengaruh yang membangun bagi perkembangan pemikiran selanjutnya.

\section{Daftar Pustaka:}

Aiken, Henry D., (2002). Abad Ideologi, terj. Sigit Djatmiko, Yogyakarta: Bentang Budaya.

al-Jabiri, Muhammad Abid, (1993). Nahnu wa at-Turats, Bairut: al-Markaz as-Tsaqafi al-Arabi.

al-Jabiri, Muhammad Abid, (2003). Kritik Pemikiran Islam: Wacana Baru Filsafat Islam, terj. Burhan, Yogyakarta: Fajar Pustaka Baru.

Aristoteles, (2004). Nicomachean Ethics: Sebuah "Kitab Suci" Etika, terj. Embun Kenyowati, Jakarta: Teraju.

Badawi, Abdul Rahman, (1995). dalam Mausuat al-Hadharoh al-'Arabiyah al-Islamiyah, Amman: Dar al-Faris, Jilid. I.

Bajjah, Ibnu, (1956). Tlm al-Nafs, Karachi: Pakistan Historical Society.

Bajjah, Ibnu, (1994). Tadbir Al-Mutawabid, Tunisia: Ceres Edition.

Bertens, K., (2011). Ringkasan Sejarah Filsafat, Yogyakarta: Kanisius.

Borgias, Fransiskus, (2013). Manusia Pengembara: Refleksi Filosofis Tentang Manusia, Yogyakarta: Jalasutra.

De Boer, T.J., (1970). The History of Pholosophy in Islam, terj. Edward R. Jones B.D., London: Lucas \& Company LTD.

Delfgaauw, Bernard, (1992). Sejarah Ringkas Filsafat Barat, terj. Soejono soemargono, Yogyakarta: Tiara Wacana.

Fakhry, Majid, (1983). A History of Islamic Phylosophy, New York: Columbia University Press.

Fakhry, Majid, (1997). Islamic Philosophy, Theology and Mysticism: A Short Introduction, Oxford: Oneworld.

Fakhry, Majid, (2002). Al-Farabi, Founder of Islamic Neoplatinosm: His Life, Works and Influence, Oxford: Oneworld.

Fakhry, Majid, (2002). Sejarah Filsafat Islam: Sebuab Peta Kronologis, terj. Zaimul Am, Bandung: Mizan.

Hasan, Fuad, (1992). Berkenalan Dengan Eksistensialisme, Jakarta: Pustaka Jaya.

Kierkegaard, Soren, (1986). Either/Or, terj. George L. Strengren, New York: Harper and Row Publisher.

Lobel, Diana, (2000). Between Mysticism and Philosophy: Sufi Language of Religious Experience in Judah Ha-Levi's Kuzari, New York: State University of New York.

Murtiningsih, Wahyu, (2012). Para Filsuf dari Plato Sampai Ibnu Bajjah, Yogyakarta: Ircisod.

Nasr, Seyyed Hossein, (2006). Islamic Philosophy from Its Origin to The Present: Philosophy in The Land of Prophecy, New York: State University of New York Press.

Nasr, Seyyed Hossein, dan Oliver Leaman (ed.), (2003). Ensiklopedi Tematis Filsafat Islam: Buku Pertama, terj. Tim penerjemah mizan, Bandung: Mizan.

Nasr, Seyyed Hossein, dan William C. Chittick, (2001). Islam Intelektual: Teologi, Filsafat, dan Ma'rifat, terj. Tim Perenial, Depok: Perenial Press, cet. III.

Russell, Betrand, (2007). Sejarah Filsafat Barat, terj. Sigit Jatmiko, Yogyakarta: Pustaka Pelajar, cet. III. 
Schopenhauer, Arthur, (1915). The Basis of Morality, terj. Arthur Brodrick Bullock, Londoh: George Allen \& Unwin, Second Edition.

Soleh, A. Khudori, (2013). Filsafat Islam: Dari Klasik Hingga Kontemporer, Yogyakarta: Ar-Ruzz Media.

Tjahjadi, Simon Petrus L., (2004). Petualangan Intelektual: Konfrontasi Dengan Para Filsuf dari Zaman Yunani Hingga Zaman Modern, Yogyakarta: Kanisius.

Tufail, Ibnu, (2010). Hayy bin Yaqdzon, terj. Nurhidayah, Yogyakarta: Navila.

Wijaya, Aksin, (2014). Nalar Kritis Epistemologi Islam, Yogyakarta: Penerbit Teras, cet. III.

Yatim, Badri, (2014). Sejarah Peradaban Islam: Dirasah Islamiah II, Jakarta: Raja Grafindo Persada.

Yazdi, Mehdi Ha'iri, (1994). Menghadirkan Cahaya Tuban: Epistemologi Iluminasionis dalam Filsafat Islam, terj. Husein Heriyanto. Bandung: Mizan.

Zar, Sirajuddin, (2012). Filsafat Islam: Filosof dan Filsafatnya, Jakarta: Rajawali Press. 